\title{
Cytological Effects of Sediment Elutriate from Tambis River System, Barobo, Surigao Del Sur in Allium cepa Root Meristem
}

\section{Dawn Rosarie M Fajardo*, Rexie P Magdugo and Iris G Deiparine}

Department of Biology, Caraga State University, Philippines

*Corresponding author: Dawn Rosarie M Fajardo, Department of Biology, Caraga State University, Philippines, Tel: 63 09154603010; E-mail: dawn.fajardo@yahoo.com

Received date: Jun 18, 2015; Accepted date: Aug 17, 2015; Published date: Aug 19, 2015

Copyright: (c) 2015 Fajardo DRM, et al. This is an open-access article distributed under the terms of the Creative Commons Attribution License, which permits unrestricted use, distribution, and reproduction in any medium, provided the original author and source are credited.

\begin{abstract}
The water resources pollution is a worldwide problem. In this manuscript, sediment elutriate (SE) from Tambis River, Barobo, Surigao Del Sur was evaluated for possible cytotoxic effect in actively dividing cells of Allium cepa root meristems. Result shows that at higher concentrations $(1000 \mathrm{~g} / \mathrm{L}$ and500 $\mathrm{g} / \mathrm{L})$ can exert mitodepressive effect, Cmitoses as a result of spindle damage, and chromosomal anomalies in actively dividing $A$. cepa root meristems with $\mathrm{P}<0.05$. This effect was dose dependent and irreversible. Exposure of Allium cepa root to sediment elutriate for $72 \mathrm{hr}$ produced significant atypical changes of chromosomes, sticky metaphases and anaphase bridges. The study suggests that cytotoxic and mutagenic effects of sediment elutriate from Tambis River was significantly higher from negative control $(P<0.05)$.
\end{abstract}

Keywords: Sediment elutriate; Allium cepa; Mitotic index

\section{Introduction}

Various studies about mutagenic chemicals have been conducted because of their effect on genes that could be passed through generations [1]. Increasing use of hazardous chemicals in small scale mining may enhance its release and exposure to environment especially in freshwater habitats. Phytotoxicity study is necessary to understand its possible effect to environment. Higher forms of plants are known as excellent genetic models to detect environmental mutagens and are frequent in monitoring studies [2]. It is well documented that among the plant species, Allium cepa has been used to evaluate DNA damages, such as chromosomal aberration and disturbances in mitotic cycle. The Allium cepa is characterized as a low cost test. It is suitable in detecting mutagens, short-term determination of water pollution level [3] and said to be an important tool for environmental monitoring studies [2]. Aside from the fact that Allium cepa test is easy to handle it is also an efficient test for chemical screening and in situ monitoring for genotoxicity of environmental contaminants [4].

Barobo is a third class municipality in the province of Surigao del Sur, Philippines and according to 2010 survey it had a population of 43, 663 people. Tambis River in Barangay Tambis, Barobo, Surigao Del Sur is a catchment basin that receives all the terrestrial runoff from the rush of small-scale gold mining. In fact, Sorex River or Tamis River System in Barobo is an area with numerous small scale mining activities for gold. In addition to that, Tambis river system is the main river system in the municipality of Barobo, running through Barangay Tambis, Bahi, Mamis, Javier, and San Jose. It passes the municipality of Tagbina and to Municipality of Hinatuan from where it flows into the Philippines Sea [5]. Along the river side, artisanal mining is very prevalent. It visually affects the river's ecosystem because of siltation and poisonous chemical like mercury that was deposited along the water system. Study of mercury analysis of fish muscles and sediments in Tambis River was conducted and concluded that there is significant difference during dry season (Unpublished thesis of Julius Anthony Leones). Although, it was also stated that the data collected in the previous study was below the standard limits of $\mathrm{tHg}$ according to USEPA and FAO. Anthropogenic activities and other human consequences might increase the rate of $\mathrm{tHg}$ concentration like the rampant artisanal small scale mining activities as been perceived in the study site. A. marmorata which is considered to be a bioindicator fish was also found along Tambis River which means that the river is already polluted.

Mercury $(\mathrm{Hg})$ is known for its use in small-scale gold miners [6,7]. Gold is extracted by adding mercury to make gold-amalgam [8]. Small-scale mining help rural inhabitant and government throughout the developing countries, if not properly monitored it can cause environmental and socioeconomic complications [9]. Various studies have proved that small-scale mining increase environmental complications such as mercury pollution and land degradation [10]. Aside from mercury, cyanide also is used in small-scale mining that is said to have a contamination impact in biodiversity, direct devastating effect on ecosystem [11]. In addition, small-scale mining can cause siltation [12] and could affect freshwater ecosystem [13]. Knowing the danger that was caused by chemical involved in small-scale mining, what would be the possible reasons for people to dwell with this kind of activity? Reasons may vary but according Aryee et. al. that was published in year 2002, small-scale miners are poor people who is dependent in mining to live. Small-scale mining or artisanal mining is a poverty driven activity that is found mainly in remote areas of developing nations [14]. They are individuals who are trapped in a vicious cycle of poverty, lacking the necessary financial and technological means to improve their standards of living [15].

This study aims to determine whether sediment elutriate from Tambis River can decrease or increase mitosis in actively dividing cells of Allium cepa root meristem. Second, to determine whether sediment elutriate from Tambis River cause C-mitosis in Allium cepa root meristem. Third, to know if sediment elutriate from Tambis River cause other chromosomal anomalies like vagrant chromosomes, 
laggard chromosomes, chromatids and chromosomes breaks, chromosome stickiness in actively dividing Allium cepa root meristem. Last, is to determine whether the cytotoxic effects of sediment elutriate from Tambis River in actively dividing cells of Allium cepa root meristem (if there is any) dose-dependent. The macroscopic effect of sediment elutriate after the treatment on the experimental onion bulb were excluded. Further, only microscopic effects of the sediment elutriate from the samples were observe. Isolation and identification of the toxicants from the sediment elutriate responsible for cytotoxic effects were not covered.

\section{Methodology}

Allium cepa (common onion) root meristems were used as an experimental system in assessing the possible cytotoxic effects of elutriates from sediments of Tambis River, Barobo, Surigao Del Sur. In search for test systems which can be combined with chemical analysis to provide data as a scientific basis for regulating the discharge of potentially hazardous substances into the environment and suitable for performance of toxicity evaluation, the Allium test [16] was proposed. This was proposed as a standard method in environmental monitoring and toxicity screening of wastewater and river water. Because of its excellent chromosome conditions, the Allium cepa chromosomes have been widely exploited for testing harmful effects of chemicals and biological materials [17]. Fiskesjo and Levan [18] and Levan [19] reported that Allium cepa test has been found to have high correlation with other test systems such as cell tests in mice, rats or humans in vivo. It could be used as an alternative to laboratory animal in toxicological research.

\section{Collection and storing of sediment samples}

Sediment samples were collected from three zones of Tambis River, Surigao Del Sur. Two days before the start of $A$. cepa assay. Samples were randomly collected from the surface sediment layer of each zone using a plastic shovel. About one kilogram of sediment samples from each zone was collected from the topmost $(5 \mathrm{~cm}$ in depth) surface sediment layer. Immediately after collection, stream debris such as rock, stick, and leaves were removed. Then, the collected sediment samples were homogenized by combining them in a plastic bucket and by mixing them thoroughly using a plastic shovel to obtain a representative composite sample [20,21].

The homogenized sediment samples were placed in polyethylene plastic bags to prevent contamination of the samples during transport from the river. The homogenized sediment samples were placed in an iced bucket during the transport. At the research room, the sediment samples were stored in a refrigerator at $4^{\circ} \mathrm{C}$ to limit biological and chemical activity until the start of the elutriation [20]. The sediment samples were kept inside a refrigerator not more than two weeks to make it still viable in the study [22].

\section{Collection of onion bulbs and root initiation}

Twenty five onion bulbs of the same variety and of the same size, weight, and quality were procured from Langihan wet market, Butuan City. The loose and the dried outer scales and old roots of the onion bulbs were removed. The brown bottom plate of the onion bulbs were cleaned by scraping the remaining soil and dirt. Extra care was observed not to remove or damage the root primordia during cleaning. While cleaning the bottom plate of the onion bulb, the root primordia was protected from drying and was kept plunge in clean tap water during the whole cleansing procedure.

Root initiation of cleaned onion bulbs were done by suspending the lower part of the bulb in $30 \mathrm{ml}$ test tubes filled with clean tap water for 2-3 days until growing roots reach the length of $1-2 \mathrm{~cm}$. During root initiation, the water level in each test tube was monitored to make sure that the root primordia is completely immersed in the water to ensure the continued growth of the roots. The water that was consumed and evaporated was replaced everyday using a sterilized syringe. To replace the water, the syringe was injected into the mouth of the test tubes without removing the onion bulbs.

\section{Elutriate preparation from sediment samples}

bioassays were conducted using sediment elutriates rather than whole sediments because the primary route of exposure for most aquatic organisms to contaminated sediment is through contact with sediment interstitial (pore) water and not the solid sediment phase directly $[23,24]$. The procedure in elutriate preparation from sediment samples was based on the methodology described by Harmon and Olive [25] with some modifications. The diluent used in the study was modified by using distilled water instead of a combination of distilled water and well water as suggested by Harmon and Olive [25]. The frozen homogenized sediments were pounded and weighed (wet weight) using an electronic weighing scale and combined with distilled water to make a $1000 \mathrm{~g} / \mathrm{l}$ sediment: water ratio.

To prepare the pure elutriate concentration, 1000 grams of the homogenized sediments was ground using the mortar and pestle. The pounded sediments were then placed in a volumetric flask and were added with distilled water up to the 1 liter mark to make $1000 \mathrm{~g} / 1$ solution. Then the $1000 \mathrm{~g} / \mathrm{l}$ solution was stirred manually for 5 minutes and was centrifuged for 5 minutes at $1500 \mathrm{rpm}$. The supernatant or the pure elutriate was decanted from the centrifuge tubes and transferred into an Erlenmeyer flask and covered tightly with aluminum foil. The collected elutriate was then stored in a refrigerator at $4^{\circ} \mathrm{C}[25]$ and was used within 72 hours for toxicity test [26].

\section{Preparation of test treatments}

Pure elutriate or $1000 \mathrm{~g} / \mathrm{l}\left(\mathrm{T}_{1}\right)$ was used as the highest test concentration. This was diluted with distilled water to make intermediate concentrations or elutriate dilutions. The tested intermediate concentrations of the elutriate were diluted properly to obtain the correct concentrations. About $500 \mathrm{ml}$ of $\mathrm{T}_{1}$ was placed in a volumetric flask and then added with distilled water until the solution reaches the 1 liter mark. The solution was then shaken to make $500 \mathrm{~g} / \mathrm{l}$ $\left(\mathrm{T}_{2}\right)$ of the elutriate. Then, about $200 \mathrm{ml}$ of $\mathrm{T}_{2}$ was placed in a volumetric flask and again added with distilled water until it reaches the 1 liter mark of the volumetric flask. The solution was again shaken to make $100 \mathrm{~g} / \mathrm{l}\left(\mathrm{T}_{3}\right)$ of the elutriate. A total of three different concentrations of the sediment elutriate were prepared and used as test treatments.

\section{Treatment of experimental onion bulbs}

The experiment was performed in a $20^{\circ} \mathrm{C}$-laboratory and onion bulbs were protected from direct sunlight. According to Kellicot as cited by Rigos [27] and Cañete [28], the cell division of the onion roots has a certain periodicity which has its maximum frequency at 12:00 noon. That is why at 12:00 noon, 30 from 50 onion bulbs with good 
Page 3 of 7

root growth were selected, transferred and were allowed to continue growing for 48 hours in $30 \mathrm{ml}$ test tubes containing each of the treatment. Treatment of experimental onion bulbs was done for 48 hours.

Treatments used in the study included $1000 \mathrm{~g} / \mathrm{l}\left(\mathrm{T}_{1}\right), 500 \mathrm{~g} / \mathrm{l}\left(\mathrm{T}_{2}\right)$ and $100 \mathrm{~g} / \mathrm{l}\left(\mathrm{T}_{3}\right)$ sediment elutriate as test concentrations, $300 \mathrm{nM}$ laboratory-prepared hydrogen peroxide as positive control $\left(\mathrm{T}_{4}\right)$ and distilled water $\left(\mathrm{T}_{5}\right)$ as negative control. Each treatment used in the study was replicated five times with one onion bulb serving as one replicate of each treatment. A total of 30 onion bulbs were treated in the experiment. During treatment of the experimental onion bulbs, used and evaporated elutriates from the test tubes were replaced using a sterilized syringe.

\section{Fixation of onion root tip cells}

In order to preserve the chromosomes of the treated onion root tip cells, the treated root tips were fixed. A fixative solution was prepared by mixing 3 parts of absolute ethanol to 1 part glacial acetic acid in a $500 \mathrm{ml}$ Erlenmeyer flask. After 48 hours of treatment, six onion root tips of about $0.05 \mathrm{~cm}$ long from the tip portion of the root was cut from each replicate bulb per treatment group at exactly 12:00 noon and was transferred immediately into small sterilized sputum containers containing the freshly prepared fixative solution. The containers were tightly covered with the containers' lid to prevent the evaporation of the fixative solution. Root tips were fixed for at least 24 hours in the refrigerator before the start of slide preparation.

\section{Slide preparation of fixed root tips}

Preparation of slides of the treated onion root tips was done using the squash technique based on the procedure described by de la Seña [29]. First, the fixed onion root tips were immersed in $1 \mathrm{~N} \mathrm{HCl}$ for 15 minutes to soften the cells and then returned to the fixative solution. Two root tips from the replicates of each treatment were randomly selected and placed separately on a clean glass slide. The root caps were cut off and discarded for no dividing cells are found in this portion of the root tip. Then, the root tips were sliced lengthwise and crosswise with a razor blade. A drop of $1 \%$ filtered acetocarmine was added to stain the root tip cells for 10-20 minutes. The slides were passed quickly over a flame for 3-5 times without boiling the stain to hasten staining. Then, each of the sliced root tips was covered with a cover slip and pressed gently but firmly with the blunt end of a ball pen against the slide and the excess stain was blotted off with a piece of tissue paper. There were two separate cover slips per slide to cover separately the two sliced root tips. To squash the cells into a thin layer, the cover slips were tapped with the blunt end of a pencil without lateral movements of the cover slip to avoid distortion of the cells. Five slides with two separately squashed root tips per treatment or a total of 30 slides were prepared and microscopically analyzed. The slides were examined under a compound microscope to check whether there were well-spread and well-stained dividing cells. Acecarmine stained the nucleus and the chromosomes only. A well-stained cell has a pink to purplish nucleus and chromosomes with transparent cytoplasm. When the prepared slide has a maximum number of dividing cells with well-stained and well-spread cells, the edges of the cover slips were sealed with 2-3 coatings of colorless nail polish.

\section{Chromosomal analysis}

Prepared slides were analyzed using a compound light microscope with a mechanical stage clip. In counting the cells, the slide was moved slowly from left to right and from top to bottom by the aid of the mechanical stage clip to avoid counting the same cell twice. To avoid bias during cell analysis, another person did the coding of the different slides and re-labeled the slides before microscopic analysis and data gathering.

A total of 1000 cells per replicate of each treatment were examined using a compound microscope at $1000 \mathrm{X}$ (10X ocular eyepiece and 100X objective) and 400X (10X ocular eyepiece and 40X objective) magnification for scoring the cytotoxic effects of sediment elutriate from the sediment samples. The total number of dividing cells, the cells with C-metaphases and $\mathrm{C}$-anaphases per replicate of each treatment was determined. The number of cells with other chromosomal anomalies like vagrant and laggard chromosomes, chromosome and chromatid breaks, and chromosome stickiness was also noted. Further, to obtain a more reliable result in the study, cells with broken or ruptured cytoplasm were not counted and scored for $\mathrm{C}$-mitoses and chromosomal anomalies since scattering and breakings of the chromosomes in these cells might be due to too much squashing during slide preparation. The collected data was used to calculate the mitotic index, percentages of cells at metaphase, percentages of cells with C-mitoses, and percentages of cells with other chromosomal anomalies.

- The mitotic index was calculated using the formula:

(Number of mitotic cells/Total number of analyzed cells) $\times 100$

- The percentage of cells with C-mitoses was calculated using the formula:

(Number of mitotic cells with C-metaphase and C-anaphase/Total number of analyzed cells at metaphase and anaphase) $\times 100$

- The percentage of cells with other chromosomal anomalies was calculated using the formula:

(Number of cells with chromosomal anomalies/Total number of analyzed cells) $\times 100$

The scoring of cells with C-mitoses (C-metaphases and Canaphases) in actively dividing onion root meristems was based on the orientation of the metaphase and anaphase chromosomes. Cells at normal metaphase stage have chromosomes with their centromeres aligned at the center of the cell and the chromosomes appear bunched midway between the poles of the cell. Cells at normal anaphase stage have chromosomes that are visible as two separated groups of $\mathrm{V}$ or Jshaped fibers directed towards the opposite poles of the cells. Cells with C-metaphase were identified as those having clumped or scattered metaphase chromosomes instead of aligned chromosomes at the center, while cells with C-anaphase were identified as those with scattered anaphase chromatids directed towards the opposite poles of the cells or with scattered anaphase chromatids at the center of the cells.

\section{Experimental design and statistical analysis}

The study was carried out using a complete randomized design (CRD) with one treated onion bulb serving as one replicate of each treatment. The selected 30 onion bulbs were randomly assigned to each treatment. Test of the different concentrations of the sediment 
elutriate and the controls were done in three replicates. The mitotic indices, percentages of cells at metaphase, percentages of cells with Cmitoses and percentages of cells with other chromosomal anomalies were subjected to one-way analysis of variance (ANOVA) or KruskalWallis Test to determine if treatment means were homogenous or not. Duncan's multiple range test (DMRT) was performed to rank and differentiate the calculated treatment means.

\section{Documentation}

Representative cells at different stages of mitosis and those with observed cytotoxic effects were photographed using a 10x ocular eyepiece, high power objectives, and Samsung digital camera under a compound light microscope.

\section{Results and Discussion}

\section{Mitotic index}

Mitosis is a process that takes place in the nucleus of a dividing cell, involves typically a series of steps consisting of prophase, metaphase, anaphase and telophase and results in the formation of two new nuclei each having the same number of chromosomes as the parent nucleus. The mitotic index (MI), is characterized by the total number of dividing cells in a cell cycle, has been used as a parameter to assess the cytotoxicity of several agents. The cytotoxicity levels of an agent can be determined by the increase or decrease in the mitotic index [2]. The mean mitotic indices of each treatment with its ANOVA and DMRT are presented in Table 1 with its raw data shown in appendix. The table shows that the mitotic indices of onion root meristems subjected to the different treatments are as follows: $7.92 \%$ for those treated with $300 \mathrm{nM}$ hydrogen peroxide $\left(\mathrm{H}_{2} \mathrm{O}_{2}\right)$ or positive control, $8.4 \%$ for 1000 $\mathrm{g} / \mathrm{L}$ SE, $11.56 \%$ for $500 \mathrm{~g} / \mathrm{L} \mathrm{SE}, 17.66 \%$ for $100 \mathrm{~g} / \mathrm{L} \mathrm{SE}$ and $20.06 \%$ for distilled water or negative control.

\begin{tabular}{|l|l|l|l|}
\hline Treatments & $\begin{array}{l}\text { Mean Mitotic } \\
\text { Index }\end{array}$ & DMRT & ANOVA \\
\hline $\begin{array}{l}300 \mathrm{nM} \text { hydrogen } \\
\text { peroxide }\end{array}$ & 7.92 & A & P value $=0.000$ \\
\hline $1000 \mathrm{~g} / \mathrm{L}$ & 8.4 & A & F comp. $=8.749^{* *}$ \\
\hline $500 \mathrm{~g} / \mathrm{L}$ & 11.56 & AB & **highly significant \\
\hline $100 \mathrm{~g} / \mathrm{L}$ & 17.66 & BC & \\
\hline Distilled water & 20.06 & C & \\
\hline
\end{tabular}

**highly significant at $\alpha=0.01$; means designated with different letters are significantly different from each other.

Table 1: Mean mitotic indices, ANOVA and DMRT of onion root meristems subjected to the different concentrations of the sediment elutriate (SE) and the controls for 72 hours.

The mitotic indices were then subjected to Analysis of variance (ANOVA) to determine if mean mitotic indices of the onion root tips exposed to different concentrations of sediment elutriate were homogenous or not. ANOVA in Table 1 shows that the mean mitotic indices of the different treatments significantly different from each other. Duncan multiple range test (DMRT) in Table 1 was done to rank the mean mitotic indices. DMRT shows that the effects of 1000 $\mathrm{g} / \mathrm{L}$ of sediment elutriate and $500 \mathrm{~g} / \mathrm{L}$ is not significantly different to
$300 \mathrm{nM}$ hydrogen peroxide which is known to have cytotoxic effect in mitotic indices [30]. Table 1 also shows that $500 \mathrm{~g} / \mathrm{L}$ and $100 \mathrm{~g} / \mathrm{L}$ are statistically similar. Table 1 further shows that onion root tip exposed to distilled water shows higher mitotic indices compared to positive control and sediment elutriates.

According to Hoshina, [31] mitotic indices significantly lower than the negative control can indicate alterations, deriving from the chemical action in the growth and development of exposed organisms. Said another way, mitotic indices higher than the negative control are results of an increase in cell division, which can be harmful to the cells, leading to a disordered cell proliferation and even to the formation of tumor tissues. But it is noteworthy to know that both the increase and reduction in mitotic indices are important indicators in monitoring environmental pollution, especially for the assessment of contaminants that are toxic and cytotoxic potential [2]. With that, Table 1 shows decreasing pattern that are statistically different from each other which says that sediment elutriates affects the normal mitotic indices of Allium cepa root tips. The decrease of mitotic cells in onion root meristems exposed to positive control and sediment elutriate might be due to the fact that they really have a harmful effect to the cell, it alters normal cell mitosis. According to Badr \& Ibrahim [32] decrease of mitotic index level shows that experimental material had mitodepressive effect resulting in the inhibition of cells access to mitosis.

\section{Percentage of cells at metaphase}

The percentage of cells at metaphase in treated A. cepa root meristems was determined to assess the cytotoxic effects of the sediment elutriate in the spindle fibers of the cell during mitosis in root meristems. If the sediment elutriate has cytotoxic components that could destroy spindle fibers during mitosis, dividing cells could be arrested at metaphase therefore, the number of cells at metaphase is expected to increase.

The mean percentage of cells at metaphase in onion root meristems subjected to the different concentrations of the sediment elutriate (SE) and its ANOVA and DMRT are presented in Table 2 shows that mean percentages of cells at metaphase in onion root meristems subjected to the different treatments are as follows: $1.4 \%$ for those exposed to distilled water, $2.16 \%$ for $100 \mathrm{~g} / \mathrm{L} \mathrm{SE}, 2.28 \%$ for $1000 \mathrm{~g} / \mathrm{L} \mathrm{SE}, 2.6 \%$ for $500 \mathrm{~g} / \mathrm{L} \mathrm{SE}$ and 2.62 for positive control.

\begin{tabular}{|l|l|l|l|}
\hline Treatments & $\begin{array}{l}\text { Mean } \\
\text { Percentage of } \\
\text { Cells at } \\
\text { Metaphase }\end{array}$ & DMRT & ANOVA \\
\hline Distilled water & 1.4 & A & P value $=0.346$ \\
\hline $100 \mathrm{~g} / \mathrm{L}$ & 2.16 & A & F comp. $=1.190^{*}$ \\
\hline $1000 \mathrm{~g} / \mathrm{L}$ & 2.28 & A & *not significant \\
\hline $500 \mathrm{~g} / \mathrm{L}$ & 2.6 & A & \\
\hline $300 \mathrm{nM}$ hydrogen peroxide & 2.62 & A & \\
\hline $\begin{array}{l}\text { *not significant at } \alpha=0.01 ; \text { means designated with letter A are statistically the } \\
\text { same from each other }\end{array}$ & \multicolumn{5}{|l}{} \\
\hline
\end{tabular}

Table 2: Mean percentage of cells at metaphase, ANOVA and DMRT of onion root meristems subjected to the different concentrations of the sediment elutriate (SE) and the controls for 72 hours. 
The mean percentages of cells at metaphase were then subjected to analysis of variance (ANOVA) in Table 2 to determine if treatment means on the percentages of cells at metaphase in onion root meristems exposed to the different concentrations of the sediment elutriate were homogenous or not. ANOVA in Table 2 shows that treatment means on the percentage of cells at metaphase are not significantly different from each other. Duncan's multiple range test (DMRT) in Table 2 was done to rank means on the percentages of cells at metaphase. DMRT shows that the percentage of cells at metaphase between the root meristems exposed to distilled water, $100 \mathrm{~g} / \mathrm{L} \mathrm{SE}$, $300 \mathrm{nM}$ hydrogen peroxide, $500 \mathrm{~g} / \mathrm{L}, 1000 \mathrm{~g} / \mathrm{L}$ are statistically similar to each other. Also, DMRT shows that as the concentration increases, the mean percentage of cells at metaphase also increases. Data gathered here shows that there is a spindle fiber fixation and there is high frequency of metaphase cells in $A$. cepa root meristems exposed to higher concentration including positive control, although the difference is not statistically significant.

\section{Percentage of cells with C-mitoses (C-metaphase and C- anaphase)}

Cells with C-metaphase were identified as those having clumped or scattered metaphase chromosomes instead of aligned chromosomes at the center, while cells with $\mathrm{C}$-anaphase were identified as those with scattered anaphase chromatids directed towards the opposite poles of the cells or with scattered anaphase chromatids at the center of the cells. C-mitoses were examined as parameters for evaluating cytotoxic effects of the sediment elutriate in actively dividing onion root meristems. The formation of spindle fibers during the metaphase and anaphase stages of mitosis could be hindered by the possible toxic components of the sediment elutriate. These toxic components could also disrupt the already formed spindle fibers which could disorganize the arrangement of chromosomes at metaphase and disorganize the movement of the chromosomes toward the opposite poles of the cells during the anaphase stage. The increased number of C-mitoses in treated onion root meristems might indicate damage to spindle fibers which could also indicate cytotoxic effect of the sediment elutriate.

\begin{tabular}{|l|l|l|l|}
\hline Treatments & $\begin{array}{l}\text { Mean } \\
\text { Percentage } \\
\text { of Cells with } \\
\text { C-Mitosis }\end{array}$ & DMRT & Kruskal-Wallis Test \\
\hline Distilled water & 3.024 & A & P value $=0.000$ \\
\hline $100 \mathrm{~g} / \mathrm{L}$ & 27.026 & B & F comp. $=19.033^{* *}$ \\
\hline $300 \mathrm{nM}$ hydrogen peroxide & 48.82 & C & **highly significant \\
\hline $500 \mathrm{~g} / \mathrm{L}$ & 69.2 & D & \\
\hline $1000 \mathrm{~g} / \mathrm{L}$ & 71.6 & DE & \\
\hline $\begin{array}{l}* * \text { highly significant at } \mathrm{\alpha}=0.05 ; \text { means designated with different letter are } \\
\text { significantly different }\end{array}$ & \multicolumn{5}{|l}{} \\
\hline
\end{tabular}

Table 3: Mean percentage of cells with C-mitoses (C-metaphase and C-anaphase), Kruskal-Wallis Test and DMRT of onion root tip meristems subjected to the different concentrations of sediment elutriates (SE) and the controls for 72 hours.
The mean percentages of cells with C-mitoses exposed to the different concentrations of the sediment elutriate (SE) with its Kruskal-Wallis test and DMRT are presented in Table 3. The table reveals that mean percentages of cells with $\mathrm{C}$-mitoses exposed to the different treatments are as follows: $3.024 \%$ for negative control, 27.026\% for $100 \mathrm{~g} / \mathrm{L} \mathrm{SE}, 300 \mathrm{nM}$ hydrogen peroxide, $500 \mathrm{~g} / \mathrm{L} \mathrm{SE}$ and $1000 \mathrm{~g} / \mathrm{L}$ SE.

The mean percentages of cells with C-mitoses in Table 3 were subjected to Kruskal-Wallis Test to determine if mean percentages in the cells with $\mathrm{C}$-mitoses among treated onion root meristems were homogenous or not. Table 3 shows that treatment means on the percentages of cells with C-mitoses are statistically different from each other. Duncan's multiple range test (DMRT) in Table 3 was done to rank treatment means on the percentage of cells with C-mitoses. DMRT reveals that the effect of $500 \mathrm{~g} / \mathrm{L}$ SE is not significantly different from $1000 \mathrm{~g} / \mathrm{L}$ SE both means are higher than hydrogen peroxide or positive control. The result of the study on the percentage of cells with C-mitoses in treated onion root meristems shows that sediment elutriate contains component/s that is/are toxic to the cell's spindle apparatus and the damage to the spindle apparatus increases as the concentration of the sediment elutriate is increased since the frequency of cells observed with C-mitoses increases with the sediment elutriate concentration. Of the tested sediment elutriate, the highest dose caused similar effect with $300 \mathrm{nM}$ hydrogen peroxide, the positive control.

C-mitoses could result from disrupted spindle fibers [33]. The spindle fibers are proteins filaments or protein ropes that make up an elaborate structure called the spindle apparatus. The spindle apparatus is critical for the separation of duplicated copies of chromosomes during mitosis within the 24 hours cell cycle of the Allium cepa.

During metaphase of mitosis, all of the stuck together pairs of sister chromatids are attached to spindle fibers on either side of the pair. The spindle fiber comes from opposite ends of the cell called the poles. When the spindle fibers attach to the pairs from opposite ends, they push and pull the sister chromatid pair likes tug-of-war and the pair ends up exactly in the middle of the cell in between the two poles. During anaphase, the spindle fibers get shorter but still are attached to the sister chromatids. When the fibers from opposite poles shorten, they pull apart the two identical chromatids [34].

\section{Percentage of cell with other chromosomal anomalies}

Chromosome aberrations or chromosomal anomalies are characterized by change in either chromosomal structure or in total number of chromosomes, which can occur both spontaneously and as a result from exposure to physical or chemical agent [35] cited by Leme and Morales [2]. In addition to that, structural chromosomal alterations may be induced by several factors, such as DNA breaks, inhibition of DNA synthesis and replication of altered DNA. The numeric CA, e.g. aneuploidy and polyploidy, are consequences of abnormal segregation of chromosomes, which can occur either spontaneously or by the action of aneugenic agents.

The mean percentages of cells with other chromosomal anomalies exposed to the different concentrations of the sediment elutriate (SE) including its ANOVA and DMRT are presented in Table 4 with the raw data shown in Appendix 19-24. The table reveals that the mean percentages of cells with other chromosomal anomalies in onion root meristems exposed to the different treatments are as follows: $0.26 \%$ for 
Page 6 of 7

negative control, $1.94 \%$ for $100 \mathrm{~g} / \mathrm{L}$ SE, 2.24\% for $1000 \mathrm{~g} / \mathrm{L} \mathrm{SE}, 2.36 \%$ for $500 \mathrm{~g} / \mathrm{L} \mathrm{SE}$ and $3.04 \%$ for positive control.

\begin{tabular}{|l|l|l|l|}
\hline Treatments & $\begin{array}{l}\text { Percentage of } \\
\text { Cell with other } \\
\text { Chromosomal } \\
\text { Anomalies }\end{array}$ & DMRT & ANOVA \\
\hline Distilled water & 0.26 & A & P value $=0.002$ \\
\hline $100 \mathrm{~g} / \mathrm{L}$ & 1.94 & $\mathrm{~B}$ & F computed $=6.346^{* *}$ \\
\hline $1000 \mathrm{~g} / \mathrm{L}$ & 2.24 & $\mathrm{~B}$ & **highly significant \\
\hline $500 \mathrm{~g} / \mathrm{L}$ & 2.36 & $\mathrm{~B}$ & \\
\hline $300 \mathrm{nM}$ hydrogen peroxide & 3.04 & $\mathrm{~B}$ & \\
\hline \multirow{2}{*}{ highly significant at $\alpha=0.05 ;$ means designated with different letter are } \\
significantly different
\end{tabular}

Table 4: Mean percentage of cells with other chromosomal anomalies, ANOVA and DMRT of onion root meristems subjected to the different concentrations of the sediment elutriate (SE) and the controls for 72 hours.

The mean percentages of cells with other chromosomal anomalies exposed to the different treatments were then subjected to analysis of variance (ANOVA) in Table 4 to determine if mean percentages on the number of cells with other chromosomal anomalies in onion root tips exposed to the different concentrations of the sediment elutriate were homogenous or not. ANOVA in Table 4 shows that the means of the different treatments as well as positive control are significantly different from negative control or distilled water. Duncan's multiple range test (DMRT) in Table 4 was done to rank treatment means on the percentage of cells with other chromosomal anomalies. DMRT shows that the effects of the sediment elutriate and positive control to exert other chromosomal anomalies are statistically different from negative control. Also, DMRT reveals that the effects of $100 \mathrm{~g} / \mathrm{L} \mathrm{SE}$, $1000 \mathrm{~g} / \mathrm{L} \mathrm{SE}, 500 \mathrm{~g} / \mathrm{L} \mathrm{SE}$ and positive control are statistically similar. Moreover, the effect of $500 \mathrm{~g} / \mathrm{l} \mathrm{SE}$ is higher than the effects of the other concentrations of the tested elutriate although the difference is not that significant.

Effects of cytotoxic substances could not just be limited to Cmitoses which are signs of disruptions in the spindle fibers. Cytotoxicity could also be evaluated by determining chromosomal anomalies in treated cells. These could be abnormalities in chromosomal structures such as chromosome breaks and fragments, chromosome bridges, sticky chromosomes and the presence of laggard chromosomes, vagrant chromosomes and polyploidy. Chromosome bridges and breaks are indicators of clastogenic action, whereas chromosome losses, delays, adherence, multipolarity and Cmetaphases result from aneugenic effects [2]. It could be possible that the observed cytotoxic effects of the sediment elutriate in $A$. cepa root meristems may be due to these toxicants which are proven to contaminate the river. But this claim has to be verified since isolation and identification of the toxicants found in the sediment elutriate was not done. Although toxicants were not identified, the results of this study must be taken into consideration since A. cepa assay has already been proven as an effective and reliable procedure in environmental monitoring [36].

\section{Conclusion}

Based on the results of the present study, the sediment elutriate from Tambis River, Brgy. Tambis, Barobo, Surigao Del Sur at higher concentrations $(1000 \mathrm{~g} / \mathrm{L}$ and $500 \mathrm{~g} / \mathrm{L})$ can exert mitodepressive effect, $\mathrm{C}$-mitoses as a result of spindle damage, and chromosomal anomalies in actively dividing $A$. cepa root meristems. The result showed that sediment elutriate from Tambis river, has cytotoxic component/s that can block mitosis, cause spindle damage resulting to C-mitoses and chromosome damage in actively dividing $A$. cepa root meristems. Moreover, the observed effects of the sediment elutriate in depressing mitosis and inducing $\mathrm{C}$-mitoses were dose-dependent at higher concentrations (from $1000 \mathrm{~g} / \mathrm{L} \mathrm{SE}$ to $500 \mathrm{~g} / \mathrm{L} \mathrm{SE}$ ).

\section{Acknowledgements}

The investigators would like to thank the local government unit of Brgy. Tambis, Barobo, Surigao del Norte for the permission to conduct a study in the said area.

\section{References}

1. Caritá R, Marin-Morales MA (2008) Induction of chromosome aberrations in the Allium cepa test system caused by the exposure of seeds to industrial effluents contaminated with azo dyes. Chemosphere 72: 722-725

2. Leme DM, Marin-Morales MA (2009) Allium cepa test in environmental monitoring: a review on its application. Mutat Res 682: 71-81.

3. Smaka-Kincl V, Stegnar P, Lovka M, Toman MJ (1996) The evaluation of waste, surface and ground water quality using the Allium test procedure. Mutat Res 368: 171-179.

4. Feretti D, Zerbini I, Zani C, Ceretti E, Moretti M, et al. (2007) Allium cepa chromosome aberration and micronucleus tests applied to study genotoxicity of extracts from pesticide-treated vegetables and grapes. Food Addit Contam 24: 561-572.

5. http://article.wn.com/view/2011/04/02/ Youth_turns_to_the_Web_to_save_river/.

6. Veiga MM, Maxson PA, Hylander LD (2006) Origin and consumption of mercury in small-scale gold mining. J Clean Prod 14: 436-447.

7. Viega MM, Baker R (2004) Protocols for environment and health assessment of mercury released by artisanal and small-scale goldminers. GEF/UNDP/UNIDO Global Mercury Project. Vienna.

8. Drasch G, Böse-O'Reilly S, Beinhoff C, Roider G, Maydl S (2000) The Mt. Diwata study on the Philippines 1999 - assessing mercury intoxication of the population by small scale gold mining. Sci Total Environ 267: 151-168.

9. Hilson G (2002) The environmental impact of small-scale gold mining in Ghana: identifying problems and possible solutions. The Geographical Journal 168: 57-72.

10. Hilson GM (2002) The future of small-scale mining: environmental and socioeconomic perspective. Futures 34: 863-872.

11. Tarras-Wahlberg NH, Flachier A, Lane SN, Sangfors O (2001) Environmental impacts and metal exposure of aquatic ecosystems in rivers contaminated by small scale gold mining: the Puyango River basin, southern Ecuador. Sci Total Environ 278: 239-261.

12. Mol JH, Ouboter PE (2004) Downstream Effects of Erosion from SmallScale Gold Mining on the Instream Habitat and Fish Community of a Small Neotropical Rainforest Stream. Conservation Biology 18: 201-214.

13. Berkman HE, Rabeni CF (1987) Effect of siltation on stream fish communities. J Environmental Biology of Fishes 18: 285-294.

14. Andrew JS (2003) Potential application of mediation to land use conflicts in small-scale mining. J Clean Prod 11: 117-130.

15. Hilson G, Pardie S (2006) Mercury: An agent of poverty in Ghana's small-scale gold-mining sector? Resources Policy 31: 106-116. 
Citation: Fajardo DRM, Magdugo RP, Deiparine RG (2015) Cytological Effects of Sediment Elutriate from Tambis River System, Barobo, Surigao Del Sur in Allium cepa Root Meristem. J Cytol Histol 6: 355. doi:10.4172/2157-7099.1000355

Page 7 of 7

16. Fiskesjö G (1985) The Allium test as a standard in environmental monitoring. Hereditas 102: 99-112.

17. Abu NE, Mba KC (2011) Mutagenicity Testing of Pharmaceutical Effluents on Allium cepa root tip meristems. J Toxicol Environ Health Sci 3: 44-51.

18. Fiskesjo G, Levan A (1993) Evaluation of the first ten MEIC chemicals in the Allium test. Altern lab anim 21: 139-149.

19. Levan A (1983) The Effects of Colchicine on Root Mitosis in Allium. Hereditas 24: 471-486.

20. UNEP, United Nations Environment Programme. 2005. Standardized Toolkit for Identification and Quantification of Dioxin and Furan Releases, second ed. Geneva, Switzerland.

21. US EPA (United States Environmental Protection Agency) (1999) Method 1568: Chlorinated Biphenyl Congeners in Water, Soil, Sediment, and Tissue by HRGC/ HRMS. Revision A. Office of Water: Engineering and Analysis Division. Washington, DC. EPA-821-R-00-002.

22. Adams WJ, Berry WJ, Burton GA, Ho K, MacDonald D, et al. (2001) Summary of SETAC Technical Workshop Pore water Toxicity Testing: Biological, Chemical, and Ecological Considerations with a Review of Methods and Applications, and Recommendations for Future. Society of Environmental Toxicology and Chemistry, Pensacola, Florida, USA.

23. Adams WJ, Kimerle RA, Mosher RG (1985) Aquatic safety assessment of chemicals sorbed to sediments. In: Cardwell RD, Purdy R, Bahner RC (eds.) Aquatic Toxicology and Hazard Assessment: Seventh Symposium. American Society for Testing and Materials, Philadelphia.

24. Adams WJ (1987) Bioavailability of neutral lipophilic organic chemicals contained in sediments. In: Dickson KL, Maki AW, Brungs WA (eds.) Fate and Effects of Sediment-Bound Chemicals in Aquatic Systems. Pergamon Press, NY.

25. Rance SH, John HO (1991) Ceriodaphnia Bioassays of Cuyahoga River Sediments, Upstream and Downstream of the Akron Water Pollution Control Station. The Ohio Journal of Science 91: 112-117.

26. Hallare AV, Seiler TB, Hollert H (2010) The versatile, changing, and advancing roles of fish in sediment toxicity assessment-a review. J Soils Sediments 1: 141-173.
27. Rigos PD (2009) Assays of Antimitotic and Toxic Effects of Selected Maranao Medicinal Plants. Biology Department, College Of Natural Sciences and Mathematics. Mindanao State University, Marawi City, Philipines.

28. Cañete, Alma May S (2011) Allium Test for Antimitotic Effects and Brine Shrimp Lethality Assay of Methanolic Extract of Pansit-pansitan (Peperomia pellucida). Biology Department, College of Natural Sciences and Mathematics. Mindanao State University. Marawi City, Phillipines.

29. de la Seña CA (2001) General Genetics Laboratory Guide and Workbook. University Book Center. Mindanao State University. Marawi City, Philipines.

30. Egito LCM, Medeiros MDG, Batistuzzo DM, Lima LF (2007) Cytotoxic and genotoxic potential of surface water from the Pitimbu river, northeastern/RN Brazil. Genet Mol Biol 30: 2.

31. Hoshina MM (2002) Avaliac, ão da possi'vel contaminac, ão das a'guas do Ribeira o Claro - munici' pio de Rio Claro, pertencente a' bacia do rio Corumbatai', por meio de testes de mutagenicidade em Allium cepa, Trabalho de conclusa o (Bacharel e Licenciatura - Cie^ncias Biolo' gicas), Universidade Estadual Paulista, Rio Claro/SP, $52 \mathrm{p}$.

32. Badr A, Ibrahim AG (1987) Effect of herbicide Glean on mitosis, chromosomes and nucleic acids in Allium cepa and Vicia faba root meristems. Cytologia 52: 293-302.

33. Cigerci IHC, Akyil D, Özkara A, Korcan SE, Konuk M (2006) Akarçay (Afyonkarahisar) suyunun mutajenik özelliklerinin Allium testi ile belirlenmesi, 18. Ulusal Biyoloji Kongresi, Aydin, 26-30 Haziran.

34. Jordan MA, Wilson L (2004) Microtubules as a target for anticancer drugs. Nat Rev Cancer 4: 253-265.

35. Russel P (2002) Chromosomal mutation. In: Cummings B (ed.) Genetics. Pearson Education Inc., San Francisco, pp. 595-621.

36. Fiskesjö G (1988) The Allium test--an alternative in environmental studies: the relative toxicity of metal ions. Mutat Res 197: 243-260. 